\title{
Regulation of Pituitary Growth Hormone-Secretagogue and Growth Hormone-Releasing Hormone Receptor RNA Expression in Young Dwarf Rats
}

\author{
REIKo HORIKAWA, ToSHIAKI TACHIBANA*, NoRIYUKi KATSUMATA, Hiroshi ISHIKAWA* AND \\ TOSHIAKI TANAKA
}

Endocrine Research Laboratoy, National Children's Medical Research Center

* Department of Anatomy II, Jikei University School of Medicine, Tokyo, Japan

\begin{abstract}
Growth hormone-secretagogue receptor (GHSR) RNA is known to be expressed in the hypothalamus and pituitary. Since endogenous GH secretagogue (GHS) is still unknown, the physiological role of GHS and GHSR in growth is not well understood. In this study, we have determined the effects of growth hormone in GH-releasing hormone receptor (GHRHR) and GHSR RNA expression in spontaneous Dwarf rats (SDRs) which are deficient in GH secretion, with or without GH replacement.

Twenty-five-day-old SDRs received daily s.c. injection of human GH $(40 \mu \mathrm{g} / \mathrm{kg} \mathrm{BW} \times 2 /$ day $)$ or control solution for two weeks. On day 40 , the rats were sacrificed by decapitation and the pituitaries were immediately removed and quickly frozen. Total RNA was extracted from the pituitary, and mRNA coding GHSR was detected and semiquantitated by competitive RT-PCR. Pituitaries from control SDRs showed strong GHSR RNA expression and the expression level was 5 to 10 times higher in females than in males. When GH was replaced, GHSR RNA expression greatly decreased. Pituitary GHRHR RNA expression, determined by RNase Protection Assay, was similar in male and female control animals; and was also greatly reduced in rats treated with GH when compared to the control. These results suggest that the expression of both GHSR and GHRHR is regulated by growth hormone, presumably via changes in hypothalamic GHRH and/or endogenous GHS. The apparent sexual dimorphism in GHSR indicates different regulatory effects of sex steroid in young growing SDRs.
\end{abstract}

Key words: Pituitary, GHRH receptor, GH secretagogue receptor, GH

(Endocrine Journal 47: S53-S56, 2000)

GROWTH hormone-secretagogue receptor (GHSR) RNA is known to be expressed in both the hypothalamus and pituitary [1]. GHS strongly stimulates GH secretion from the pituitary [2], but because the role of endogenous GHS is still unknown the physiological role of GHS and GHSR in growth is not well understood. On the other hand, GHreleasing hormone (GHRH) and its receptor (GHRHR) on the pituitary are known to be the main regulators of pituitary GH secretion and also of somatotroph proliferation. We have studied de-

Correspondence to: Reiko HORIKAWA, Endocrine Research Laboratory, National Children's Medical Research Center, Taishido 3-35-31, Setagaya-ku, Tokyo 154-8509, Japan velopmental changes in GHRHR and GHSR in pituitaries from young growing rats and reported that GHRHR and GHSR RNA expression in the pituitary increased with pubertal development and there appeared sexual dimorphism in late-puberty [3]. Interestingly, the developmental changes in expression of GHRHR and GHSR were not identical; GHSR RNA showed signs of more similar changes to somatostatin type II receptor. We also demonstrated that gonadectomy in the prepubertal period increased pituitary GHRHR and GHSR RNA expression in both male and female rats [4], suggesting that sex steroids suppress this RNA expression.

Spontaneous Dwarf Rats (SDRs) are genetically GH deficient strain [5]. Because SDRs have a dele- 
tion in the GH gene which leaves these animals completely GH deficient [6], SDRs are good models for studying the effects of $\mathrm{GH}$ on various kinds of gene expression. In this study we investigated the effect of growth hormone in pituitary GHRHR and GHSR RNA expression by using Spontaneous Dwarf Rats.

\section{Materials and Methods}

\section{Animal Experiment}

Twenty-five-day-old SDRs (males and females) were divided into four groups: male rats with an injection of control solution (solution to dissolve hGH) (group I: male control group), male rats with GH treatment (Group II), female rats with control solution injection (group II: female control group), female rats with GH treatment (group IV). Rats were treated with a subcutaneous injection of control solution or recombinant human GH at a dose of $40 \mu \mathrm{g} / \mathrm{kg}$ body weight, twice daily for two weeks. The animals were sacrificed by decapitation at day forty, twelve hours after the last $\mathrm{GH} /$ control solution injection. The pituitaries were immediately removed and kept in $-70^{\circ} \mathrm{C}$ until use.

\section{$R N A$ analysis}

Total RNA was extracted from the removed pituitaries by the guanedinium thiocyanate-phenol chloroform method. RNA for GHRHR was detected and quantitated by RNase protection assay, as previously described [3]. Rat pituiraty GHSR was detectable by RNase protection assay even in young rats, but the message levels were too low to be quantitated. Thus we developed quantitative RTPCR by construction of competitor RNA. Briefly, rat GHSR cDNA from transmembrane 1 to 5 was subcloned into $\mathrm{pBK}-\mathrm{CMV}$ vector, and a mutant with $89 \mathrm{bp}$ deletion in the center of the clone was synthesized by recombinant PCR and served as a competitor. The competitor RNA for competitive RT-PCR was transcribed from the mutant with deletion by Maxiscript kit (Ambion) as shown in Figure 1. $0.5 \mu \mathrm{g}$ total RNA (per tube) with various amounts of competitor RNA was reverse-transcribed by oligo-dT and random priming. The product was subjected to PCR-amplification with specific primers for transmembranes 1 and 5 of GHSR. The amplified PCR products were detected and analyzed by phosphorimager.

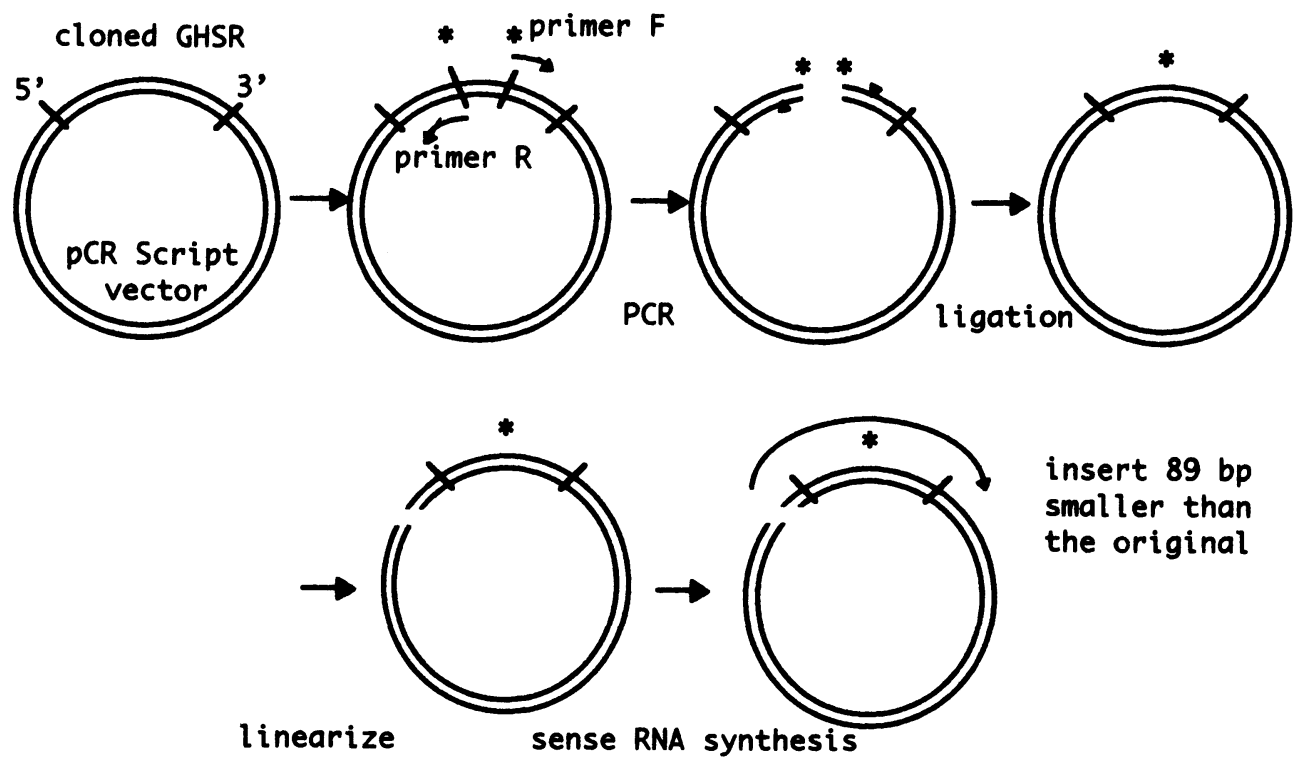

Fig. 1. 


\section{Results}

Rat pituitary GHRHR RNA was quantitatively detected by RNase protection assay, as previously described [3]. Pituitary GHSR was detectable by RNase protection assay in all age groups, but the message levels were too low to be quantitated. Thus we used competitive RT-PCR for quantitation of GHSR RNA. The products from competitive RTPCR were detected on polyacrylamide gel (Figure 2). By this method the message level of $150 \mathrm{pg}$ RNA (the lowest amount tested) was detectable.

The one to one ratio of competitor and the original pituitary RNA which were transcribed and PCR amplified was designated as the amount of RNA specific for GHSR (Table). The GHRHR and GHSR message levels in the SDR pituitary were higher than in pituitaries from 35-day-old Sprague-Dawly rats. In SDRs, GHSR RNA expression was about ten times higher in female rats than in male rats, but GHRHR RNA expression did not show any sign of sexual dimorphism. Treatment with GH suppressed the expression levels of GHRHR and GHSR in both male and female rats. GHSR RNA was still lower in males than in females even after GH treatment.

\section{Discussion}

Our previous studies on pituitary GHRHR and GHSR RNA expression in normal Sprague-Dawly rats showed that: 1) RNA expression per total RNA first decreased with age up to day 20 and then rapidly increased during puberty in rats, 2) RNA expression in males and females did not significantly differ by
Table 1. Replacing amount of competitor RNA $(\mu \mathrm{g})$

\begin{tabular}{ccc}
\hline & control & GH treatment \\
\hline Male & $1 \times 10^{-6}$ & $1 \times 10^{-7}$ \\
Female & $1 \times 10^{-5}$ & $1 \times 10^{-6}$ \\
\hline
\end{tabular}

Pituitaries from female SDRs showed higher GHSR RNA expression than those from male.

GH treatment markedly reduced GHSR RNA expression in both male and female SDR pituitaries.

day 20 in both GHRHR and GHSR, but the GHRHR RNA expression tended to be higher in males at day 35, whereas GHSR expression became higher in males at day 45,3 ) gonadectomy at day 20 increased GHSR RNA expression in both sexes when determined at day 35 [4]. This study showed a marked increase in GHRHR and GHSR RNA expression in $\mathrm{GH}$ deficient rats and a reduction in RNA with $\mathrm{GH}$ treatment.

Neither gonadal sex steroids nor growth hormone contributed to the increase in pituitary GHRHR or GHSR RNA expression during puberty. SDRs are congenital GH deficient strain with GH gene deletion. The cell population of somatostatin (SS) in the periventricular nucleus (PN) and GHRH in the arcuate nucleus (ARC) of SDRs and normal rats were studied by immunohistochemistry [6]. The SS perikarya in the PN of SDRs were significantly reduced, but the GHRH perikarya in the SDRs were significantly increased. These results and ours suggest that GH itself acts on GHRH synthesis in a negative regulatory manner, and increase in GHRH by primary isolated $\mathrm{GH}$ deficiency in turn increases pituitary GHRHR synthesis. The regulation of GHSR is still not understood. Pituitary GHSR RNA

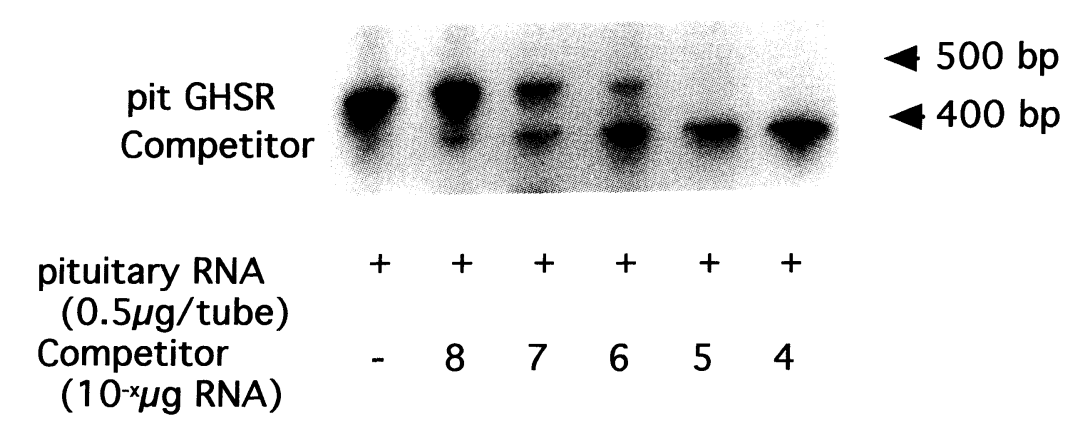

Fig. 2. Autoradiograph of competitive RT-PCR for pituitary GHSR 
expression might be mainly regulated by hypothalamic GHRH or the endogenous natural ligand for GHSR. In adult SDRs, increased expression of pituitary GHRHR and GHSR is also reported [7, 8].
The developmental changes, especially the rapid increase in pituitary GHRHR and GHSR expression may be, at least in part, due to the increase in hypothalamic GHRH.

\section{References}

1. Howard AD, Feighner SD, Cully DF, Arena JP, et al. (1996) A receptor in pituitary and hypothalamus that functions in growth hormone release. Science 16: 974-977.

2. Bowers CY, Reynolds GA, Durham D, Barrera CM, Pezzoli SS, Thorner MO. (1990) Growth hormone (GH)-releasing peptide stimulates GH release in normal men and acts synergistically with GH-releasing hormone. J Clin Endocrinol Metab 70: 975-982.

3. Horikawa R, Katsumata N, Tanaka T, Tanae A (1998) Ontogeny of pituitary receptors for growth hormone-releasing hormone, somatostatin, and growth hormone-secretagogue. Horumon to Rinsho 46: 997-1000 (in Japanese).

4. Horikawa R, Katsumata N, Tanaka T, Tanae A (1998) The regulatory effect of sex steroids on RNA expression of pituitary growth hormone-releasing hormone receptor and growth hormone secretagogue receptor in young growing rats. The 33d annual meeting of Japanese Society for Pediatric Endocrinology (Abstract).

5. Takeuchi T, Suzuki H, Sakurai S, Nogami H, Okuma
S, Ishikawa H (1990) Molecular mechanism of growth hormone $(\mathrm{GH})$ deficiency in the spontaneous dwarf rat: detection of abnormal splicing of GH messenger ribonucleic acid by the polymerase chain reaction. Endocrinology 126: 31-38.

6. Sakuma S, Ishikawa H, Okuma S (1990) The cell population of somatostatin and growth hormonereleasing factor using quantitative immunohistochemistry in the isolated GH deficient dwarf rat. Brain Res 506: 307-310.

7. Kamegai J, Unterman TG, Frohman LA, Kineman RD (1998) Hypothalamic/pituitary-axis of the spontaneous dwarf rat: autofeedback regulation of growth hormone (GH) includes suppression of GH releasinghormone receptor messenger ribonucleic acid. Endocrinology 139: 3554-3560.

8. Kamegai J, Wakabayashi I, Miyamoto K, Unterman TG, Kineman RD, Frohman LA (1998) Growth hormone-dependent regulation of pituitary $\mathrm{GH}$ secretagogue receptor (GHS-R) mRNA levels in the spontaneous dwarf rat. Neuroendocrinology 68: 312318. 